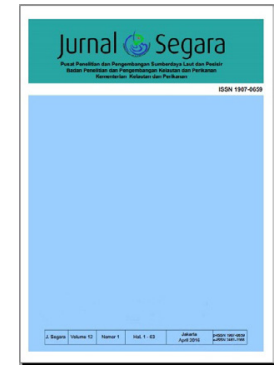

JURNAL SEGARA

http://ejournal-balitbang.kkp.go.id/index.php/segara

ISSN : 1907-0659

e-ISSN : 2461-1166

Accreditation Number: 766/AU3/P2MI-LIPI/10/2016

\title{
PROGRESS ON COASTAL ECOSYSTEMS: CORALS AND MANGROVES RECOVERY 12 YEARS LATER AFTER MARCH 2005 EARTHQUAKE IN NORTH NIAS, NORTH SUMATERA
}

\author{
Suyarso, Bayu Prayuda \& Praditya Avianto \\ Research Center for Oceanography - Indonesian Institute of Sciences, Jakarta \\ Received: 23 August 2016; Revised: 22 May 2017; Accepted: 15 July 2017
}

\begin{abstract}
Twelve years ago 9.3 Mw earthquake in the Andaman Islands, on December 26, 2004 accompanied by the tsunami in Aceh led to extraordinary losses, unprecedented for human life in coastal areas of Indonesia and neighboring countries. A few months later, on March 28, 2005 an earthquake $8.7 \mathrm{Mw}$ has occured around Nias, hundreds of hectares of coral reef ecosystems lifted into the terrestrial, many corals died of drought and collapse due to earthquake vibration. Similarly, most of the mangrove moved away from the coastline due to land lifting. The purpose of this study is to determine the development of coastal ecosystems, especially coral reefs have been damaged by the earthquake and mangrove due to changes in the environment. The method used in this study is remote sensing technique through the data acquired from landsat imageries, measurements of coastal profile, coral reef health monitoring data collected in each year at six permanent stations. The field surveys were conducted in August 2005, December 2014 and December 2015, the last two activities were under research collaboration between the Marine Agency of North Nias Regency and Research Center for Oceanography LIPI. The results showed in the period 2007-2010 live coral coverage is likely to increase in the range between $2.23 \%$ to $48 \%$. Instead since 2014 showed a significant decrease in almost all stations. Twice earthquakes with 33the magnitude $8.2 \mathrm{Mw}$ and $8.6 \mathrm{Mw}$ occurred almost simultaneously on April 11, 2012 at $400 \mathrm{~km}$ southwest of Aceh is thought to play a role in tear down the developing corals. Similarly, the existence of mangrove that has moved away from the coastline due to the land lifting in 2005, species of Rhyzophora desiccated and died slowly but other species such as Aegiceras, Dolichandrone, Xylocarpus and Cheriops appear stayed on the dry land condition and seemed to be growing normally.
\end{abstract}

Keywords: coastal ecosystems, recovery 12 years later, March 2005 earthquake, North Nias, North Sumatera.

\section{INTRODUCTION}

The natural resources of coastal and shallow waters surroundings are important factor in supporting the life community. Valuable resources in the coastal and shallow waters ecosystems in tropical hemisphere are coral reefs, seagrass and mangrove. The degreded of coastal ecosystem due to the change of physical environment factor naturally or anthropogenic factor, causing disruption of the ecosystem function, ecologically and economically. Natural factors that play an important role on the changes of coastal environment are weather or climate, geological phenomena such as earthquakes which are sometimes cause the tsunamic and land uplifted events. Anthropogenic factors are waste effluents from the mainland and excessive utilization of natural resources causing increasing turbidity in the water environment, even the presence of toxic chemicals will damage corals and other organisms.

Due to a potential enormous of the coastal resources, various parties want to capitalize, indicated by a various utilization, cause over exploitation and exceeds of environment carrying capacity (Tugiyono, 2010). Therefore, the widely use and multi function of coastal ecosystem between economic and conservation interests make it difficult to manage the coastal environment (Vitria, 2010; Saraswati, 2004).

Coral reefs generally live in the outer edge of the shallow marine environment, as a high productive

Corresponding author:

Jl. Pasir Putih I Ancol Timur, Jakarta Utara 14430. Email: Suyarso_lipi@yahoo.com 
ecosystem, built by the colony of marine animals (Anthozoa). Those animals collect the calcium carbonate to build the habitat structure for other organisms. Seagrass is a flowering plant attached on the surface substrate in the shallow waters that is also a common found in coral reef ecosystems, that the life cycle is in saltwater environments and able to stabilize the substrate. Mangrove is a component of the coastal ecosystem growing in tropical climates along the coast or a river mouth of the tidal range, contributes substantial economy to coastal communities, but they are very fragile against both natural factors and human activity. (Tugiyono, 2010; Dahdouh-Guebas, 2002).

Twelve years ago 9.3 Mw earthquake at Andaman Islands, occurred in December 26, 2004 was followed by tsunami event in the region of Aceh causing tremendous losses, unprecedented for human life in coastal areas of Indonesia and neighbouring countries. It was recorded 300,000 people died in countries along the shores of the Indian Ocean by a violent wave. A few months later, on March 28, 2005, 8.7 Mw earthquake has occurred, and destroyed most of the buildings on the Nias Island (Hagan et al., 2007). Although the quake was not followed by a significant tsunami event, it event has caused land lifting of Nias Island and changed the northern surrounding shallow waters to become a new land. The impact of natural disaster destroy a various coastal vital objects in Nias (Vargas et al. ,2011; Devi \& Shenoi, 2012), changed the geography and geomorphology of the coastal areas (Villalobos, 2012), the coastal and beach profiles (Vargas et al., 2011), the configuration of the shoreline and coastal ecosystem (Mc Adoo et al., 2008). Based on the remains of micro attols, Suyarso (2005) reported that the northern part of the island of Nias rose in the range between $2.50 \mathrm{~m}$ to $2.60 \mathrm{~m}$ above the present sea level. On April 11, 2012 again, the great Sumatera earthquake occurred at $400 \mathrm{~km}$ southwest off Aceh with the magnitude $8.6 \mathrm{Mw}$ and 2 hours later followed by another quake approximately $200 \mathrm{~km}$ to the south with the magnitude $8.2 \mathrm{Mw}$.

Destruction of coral reefs by the quake even though accompanied by a tsunami, the vibration of quake give higher damaged on the coral reefs. The data presented shows how the relation of coral condition and quakes occurrence.

\section{METHODOLOGY}

Site location of the research was done in North Nias Regency which is consists of 11 districts, in this study only 4 districts will be discussed, namely Lahewa, East Lahewa, Lotu and Sawo District.

Field research on coastal was done in August 2005, in the end of December 2014 and 2015. Both the last are on the framework of research cooperation between the Marine Agency of North Nias Regency and the Research Centre for Oceanography - LIPI related on the project Potential Resource Evaluation of the North Nias waters. Coral health monitoring has been conducted since 2004 to 2015 on behalf of World Bank and Asian Development Bank through the coral reef monitoring project of Coremap - LIPI from 2004 to 2010 and 2014 to 2015 at six permanent stations (Figure 1). The data then presented in the graph describing between time (year interval in $\mathrm{x}$ axis) versus the percentage of coral growth progression (y axis).

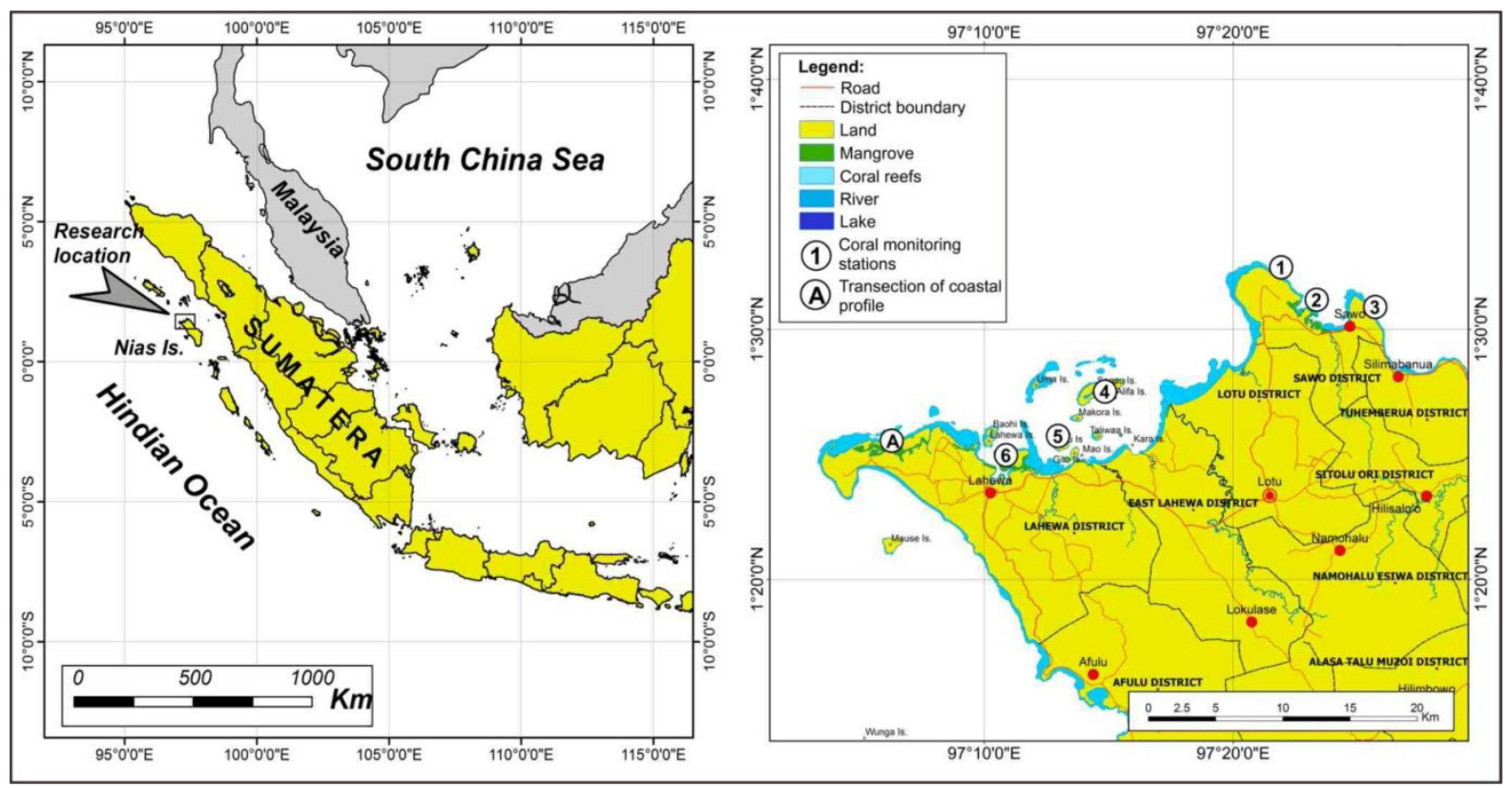

Figure 1. Inset of research location (left) and a map of the study sites and permanent stations of coral monitoring at North Nias Regency (right). 
Earthquake data consist of the location of the earthquake occurence (longitude, latitude), the time of the earthquake as well as the magnitude of the quake around Nias 2005 to 2015 from the USGS 2016. This data will be used to complete the progressing the coastal ecosystems analysis of North Nias quake in March 2005 and 10 years later.

Measurement and drawing of coastal profile was conducted in August 2005 using geodetic instrument (Sokhiza type B2C, rods / staffs, global positioning system and tide gauge). This instrument is used to calculate the distance and the difference high among places with accuracy up to a centimeter. Measurements using such instrument, can calculate the distance between mangroves and the shorelines and the high of mangroves high relative to mean sea level so the actual coastal profile can be drawn with the real scale.

Field ground thruth which was conducted in December 2014 and December 2015, describe the coastal land cover, mangrove distribution and coastal morphology. Data of shallow water substrates was performed using the boat and the geographic coordinates is recorded with using GPS Garmin 76c These data then presented in a map by using Arcgis software.

Landsat imagery aquired 2003 describes the condition of the Nias coast before the earthquake in Nias while landsat imagery aquired 2015 describes conditions 10 years after the earthquake. Those of landsat imageries were analyzed using remote sensing techniques. The purpose of this analysis is to get an image of the earth's surface more sharply. As we know rayleigh scatter in the atmosphere can produce thin fog which have a stronger effect on the shorter wavelength bands (Lillesand \& Kiefer, 1990; Mishra et al., 2006), hence the image of the earth's surface obtained from landsat becomes faded and vague. The method used for atmospheric correction is dark pixel subtraction (Spitzer \& Dirks, 1987; Armstrong, 1993; Maritorena, 1996). A large number of pixels are sampled from the darkest area at deep water and their average value in each band then it is used to subtract from all other pixels in each band respectively:

\section{Atmospherically corrected radiance $=\mathrm{Li}-\mathrm{Lsi}$}

Where:
$\mathrm{Li} \quad$ is the pixel radiance in band $\mathrm{i}$ and
Lsi is the average radiance for deep water in
band $\mathrm{i}$.

The new composite image generated from the algorithms and combination among chanals would seems more obviously, boundaries of mangroves and other vegetations can also be clearly identified.
Furthermore the new images composite obtained from the algorithm was transformed into Arcgis format and digitized manually, so it will be obtained a map of shallow waters and mangrove ecosystems in North Nias 2003 and 2015, respectively.

\section{RESULTS AND DISCUSSION}

\section{The changes of physical condition coastal and land environment}

Nias earthquake occurred in 5 March 2005, showed that the land in North Nias has lifted as high as $2.50 \mathrm{~m}$ to $2.60 \mathrm{~m}$ above sea level. The catastrophic events has led to the changes of physical environment as the land increase broadly, the emergence of some new islands, change the height of the mangrove plants to sea level, and death of coral reefs in shallow waters due to drought and collapse of coral reefs in the deeper waters by quake vibration (Mc Adoo et al., 2008).

In the north coast of Lahewa, showed increasing the new lands after earthquake with a width ranging from $200 \mathrm{~m}$ to $800 \mathrm{~m}$. The land cover of the highest topographic on the new land now are open land and grasses field while the lowest topographic formed the swamp. The lowest topographic in the new land previously were lagoons in the coral reef ecosystem.

The changing of geographic visible clearly shown on the small islands north of Lahewa coast, i.e. Lafau Island, Gito Iland, Taliwaa Island, Sanau Island and Makora Island (Figure 3). On the pre of earthquake, the coral reef ecosystems has a wider ranges in between $100 \mathrm{~m}$ up to $400 \mathrm{~m}$. After the earthquake, the coral in shallow water is lifted and partly forming the new islands. (Table 1). The remaining coral reefs ecosystem after the quake are relatively narrower than the coral reefs ecosystem at the pre earthquake. Comparison of the physical environment in North Nias in 2003 and 2015 is shown in Table 1.

\section{Changes of the coral reef ecosystem}

Coral reefs ecosystem in North Nias on pre earthquake is wider than after earthquake (Figure 3 ). In Lahewa District, coral ecosystems reaches 1300 $\mathrm{m}$ wide from the coastline while in East Lahewa, Lotu and Sawo districts are only range in between $25 \mathrm{~m}$ up to $350 \mathrm{~m}$. Since the Nias earthquake mostly coral ecosystems, particularly coral with the less than 2.5 $\mathrm{m}$ depth has been raised and transformed into the land. The waters north coast of Lahewa District, based on landsat imagery aquired 2003 were small islands surrounded by coral reefs. There are six islands in the area (Table 2): Island of Sanau, Taliwaa, Makora, Lafau, Gito and Mause. On the Sanau Island, in the pre earthquake there was a lagoon, water mass circulation 

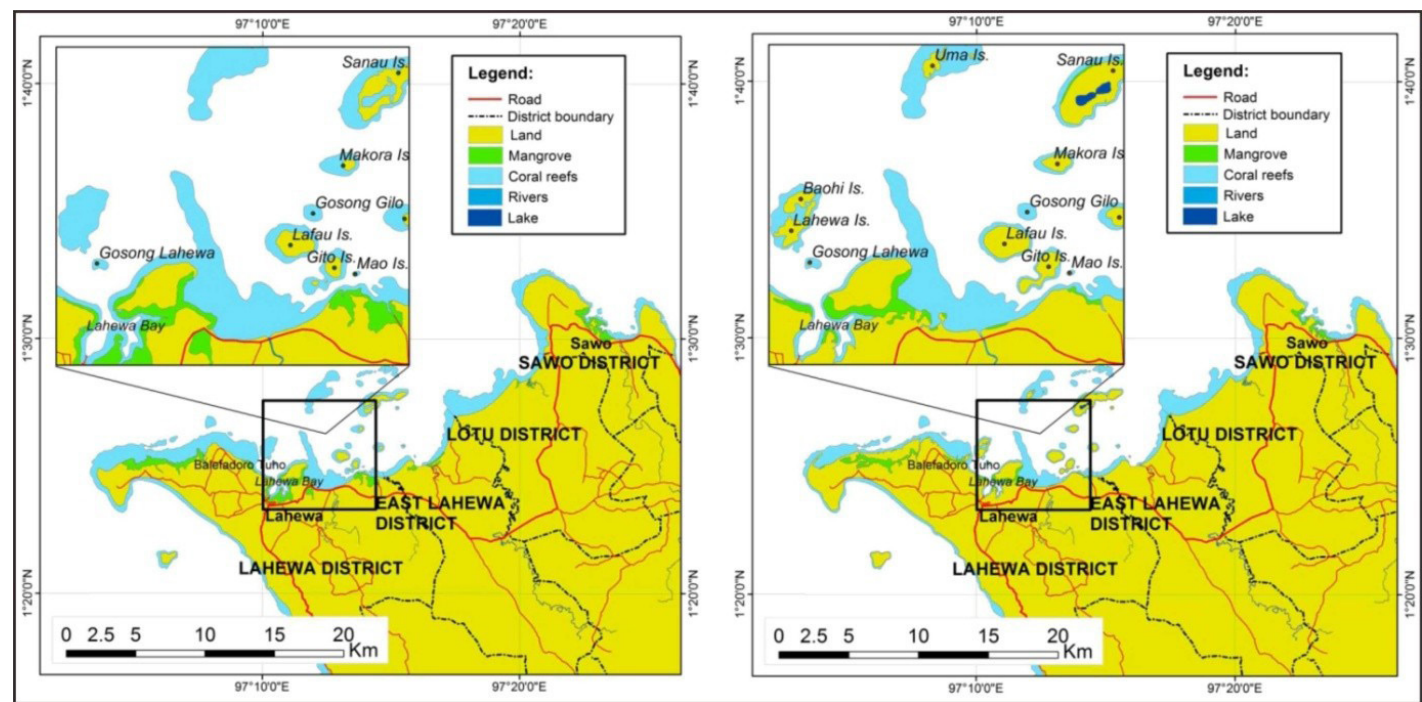

Figure 2. Changes of physical environment of Sanau Island. Upper left: Sanau Island before the quake showed lagoon with two channels and swamps. Upper right: Sanau Island after the quake, the former of lagoon altered into a saltwater lake. Lower left: reef flat, embryonic of Uma Island before the quake, bottom right: Uma Island, which is the island that formed after the quake.

Table 1.

Comparison in hectare unit of area before (2003) and after the quake (2015)

\begin{tabular}{llll}
\hline No & Location & 2003 (before quake) & 2015 (after quake) \\
\hline 1 & Lahewa District & 15952.37 & 16842.31 \\
2 & East Lahewa District & 12435.87 & 12706.0 \\
3 & Lotu District & 11566.15 & 11611.15 \\
4 & Sawo District & 4899.53 & 4940.56
\end{tabular}

\begin{tabular}{llll}
\hline Existing islands & \\
\hline 1 & Sanau Island & 128.12 & 220.70 \\
2 & Taliwaa Island & 5.33 & 18.58 \\
3 & Makora Island & 6.68 & 22.25 \\
4 & Lafau Island & 45.62 & 68.45 \\
5 & Gito Island & 16.60 & 39.76 \\
6 & Mause Island & 60.07 & 99.42
\end{tabular}

\begin{tabular}{llll}
\hline \multicolumn{3}{l}{ New islands formed after quake } & \\
\hline 1 & Gosong Lahewa Island & - & 0.59 \\
2 & Lahewa Island & - & 34.85 \\
3 & Boahi Island & - & 23.27 \\
4 & Uma Island & - & 20.87 \\
5 & Kara Island & - & 0.27 \\
6 & Siene-ene Island & - & 0.51 \\
\hline Coral reef ecosystem & & \\
\hline & & & \\
2 & Lahewa District & 2961.54 & 1859.73 \\
3 & East Lahewa District & 301.35 & 239.97 \\
4 & Lotu District & 764.46 & 722.28 \\
5 & Sawo District & 832.91 & 712.91 \\
\end{tabular}




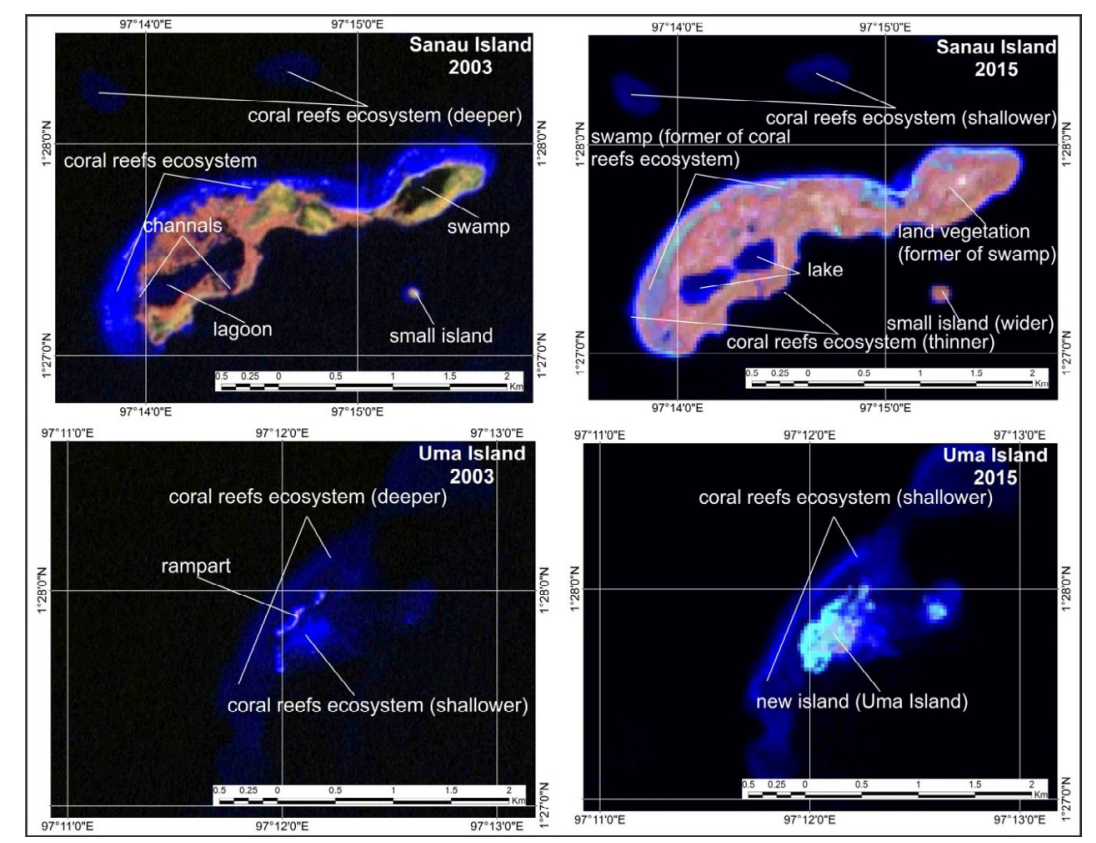

Figure 3. Comparison of coral reefs ecosystem and mangrove in North Nias, left: coral reefs ecosystem and mangrove in 2003 (before the quake), right: coral reefs ecosystem and mangrove in 2015 (after the quake).

connected to the open sea through two canals (Figure 2). After the quake, canals were lifted and closed causing this lagoon changed become a saltwater lake with the salinity higher than the salinity of the sea water surroundings .

\section{Seismicity}

The bottom of the waters in west of Sumatra is a part of the active tectonic system of Indonesia Islands Arc. They are located on the subduction zone that is a convergent tectonic plates. which is the Indo-Australia plate moves to north underneath the Eurasian plate (Katili, 1974; Chasanah et al., 1995; Handayani et al. 1995) with average velocity $52 \mathrm{~mm} /$ year (USGS 2008). The condition causes the western part of Indonesia Islands Arc is a region with active of seismicity.

Since the periode of $2000-2016$, in western Sumatra region was recorded more than 1500 quakes with the magnitude of over $5 \mathrm{Mw}$ (USGS, 2016). The quake center was found at Andaman on December 26, 2004 with a magnitude of Mw 9.1 while Nias quake on March 28, 2005 with a magnitude of Mw 8.6, and on April 11, 2012 were recorded twice of quakes with a magnitude of over $8 \mathrm{Mw}$. The first quake had a magnitude of $8.6 \mathrm{Mw}$ at $15: 38 \mathrm{pm}$ and the center was located the West coast of Sumatra. Two hours later was followed the second quake with a magnitude of $8.2 \mathrm{Mw}$ located in the $200 \mathrm{~km}$ south of the first earthquakes (Figure 4, left). Duputel et al. (2012) mentioned that the quakes occurred in the oceanic lithosphere of Cocos Basin. The vibration of the two quakes felt up to India,
Bangladesh, Singapore, Malaysia and Thailand, even some of those countries evacuated residents around the beach to anticipate of the tsunami (BBC News ,2012), Theguardian April (2012) was also reported panic and traffic jams triggered in Aceh after postearthquake tremors also felt in Singapore, Thailand, Malaysia and India.

\section{The monitoring of the live coral coverage}

Program of coral reef monitoring in North Nias has done since 2004 located at 6 stations (Figure 1), in the reef slopes environment with the depth of $6 \mathrm{~m}$ to $9 \mathrm{~m}$. Progress of the live corals percentage since 2004 to 2015 is shown in the Figure 4 (right), there was no data in 2011 to 2013 because in that period the monitoring activity was not performed. In 2007 monitoring data still shows the live coral cover decrease with a range in between $2 \%$ to $4 \%$. In the period 2007 to 2010 shows increasing ith the range $12.3 \%$ to $32.7 \%$ except on station 2, there was no change of live coral cover since 2005. The data 2014 showed a decrease of $1.3 \%$ to $35.6 \%$ of coral especially at station $1,3,4$ and 6 while on station 5 shows an increase continuously.

\section{The changes of mangrove ecosystem}

In the pre Nias earthquake March 25, 2005 mangrove ecosystem in Lahewa District shows spacious, extends along the northern coast with an area of approximately 600 hectares (identified on the landsat imagery in 2003). After quake, Nias mainland has been lifted up as high as $2.5 \mathrm{~m}$ causing mangrove 


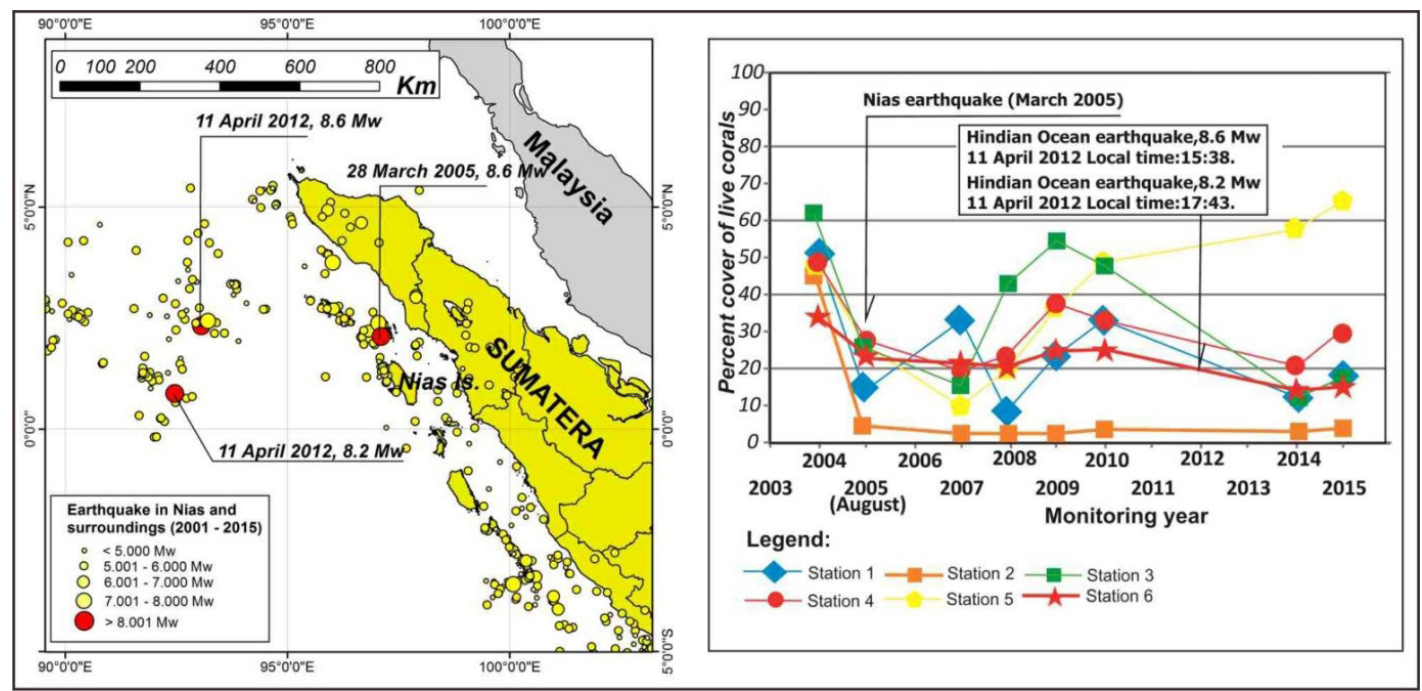

Figure 4. Left: a map of the earthquake distribution with the magnitude recorded in the periode $2000-2016$ on the western side of Sumatra, right: graph shows progression of the live coral coverage in North Nias since 2004 to 2015 from reef health monitoring results.

vegetation move $500 \mathrm{~m}$ away from the shoreline. Landsat image in 2015 (10 years after Nias quake) shows that mangrove farthest from the shoreline have largely been destroyed and changed into land vegetations. Otherwise mangroves nearest to the shoreline shows the spreading progression toward the north, approach to the shoreline. The spreading progression of mangroves for more than 10 years in some places reaches up to $200 \mathrm{~m}$ wide. In the coastal areas in Lahewa and Balefadoro Tuho villages, the new mangrove plants began to grow sporadically with the thickness from the shoreline up to $50 \mathrm{~m}$ including Rhizophora apiculata, Rhizophora mucronata, and Xylocarpus granatum.

Around East Lahewa District until the Lotu District, the mangroves grew scattered around the mouth of the Mosoi River, and developed after the Nias earthquake. In Sawo District, mangroves found in the Bengkuang village. On the pre earthquake mangrove in the region was 177.35 hectares, but after the earthquake in 2005 partly mangrove, particularly those farthest from the coastline destroyed and leaving only 102.84 hectares. These types of mangrove consist of Rhizophora apiculata, Rhizphora lamarchii, Rhizophora mucronata,
Bruguiera gymnorrhiza, Lumnitzera littorea, Ceriops tagal, Nypa fruticans, Acrostichum aureum, Xylocarpus granatum and Sonneratia alba. Changes of mangrove area before quake (2003) and after the quake (2015) (in hectares) is shown in the Table 2.

\section{Recovery progress of the live coral coverage}

In Figure 4 shown that the impact of the earthquake occurred in Nias on March 28, 2005 with a magnitude $8.7 \mathrm{Mw}$ has caused a decrease of live coral coverage i.e. $11.7 \%$ to $40.23 \%$. In the period 2007 to 2010 showed that the percentage of live coral coverage tend to increase with the range in between $2.23 \%$ to $48 \%$. Monitoring data collected in 2014 ironically that the live coral coverage decreased significantly at almost all stations. The coral damage occurring in Nias in 2014 was the collapse of live coral and the increase significantly of coral rubbles in the deeper part. Twice quakes as reported by both BBC News (2012) and public panic in mainland of Sumatera (Theguardian, 2012) indicated that the quakes vibration felt very strong. In relation to coral damage, Mc Adoo et al. (2008) showed much evidence that vibration of earthquake more destructive rather than tsunami in

Table 2.

Comparison of the mangrove area before quake (2003) and after the quake (2015) (in hectares) in North Nias.

\begin{tabular}{llll}
\hline No. & Districts & 2003 (before quake) & 2015 (after quake) \\
\hline 1 & Lahewa District & 592.86 & 331.84 \\
2 & East Lahewa District & 44.47 & 9.23 \\
3 & Lotu District & 18.15 & 8.53 \\
4 & Sawo District & 177.34 & 69.71 \\
\hline
\end{tabular}




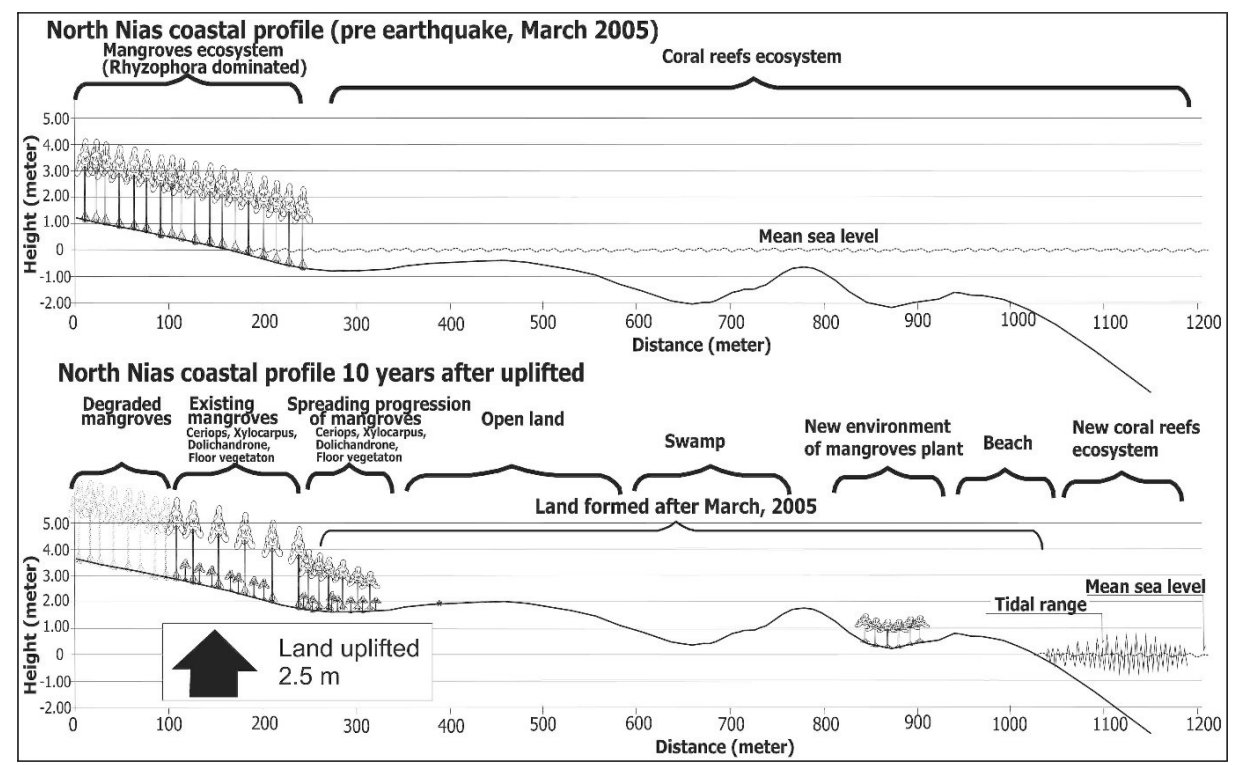

Figure 5. The change of coastal profiles and its impact to the development of the mangrove in the West of Lahewa village. Upper: coastal profile before land uplifted due to Nias Earthquake, March 2005, lower: coastal profile after land uplifted.

the Solomon Islands. Acceleration of vibration will be stronger, especially on the reef slope area, brancing and table corals collapse and fall on the top of fine sediments in the deeper waters. The same phenomena has also been reported by Aronson et al. (2012) in their research in Belizean Barrier Reef lagoon, western Caribbean, especially on the reef slopes dominated by branching corals. Collapse of semi consolidated reef debris was triggered by vibration developed during the earthquake, breaking free and sliding into deeper water.

The quakes of $8.2 \mathrm{Mw}$ and 8.6 Mw on April 11, 2012 quakes might play an important role in damaging of the live coral cover which was recorded in 2014 in North Nias. However, at station 5 the quake seem not affected to live coral coverage. This station is dominated by recruitments of branching live coral grows on the hard corals that the topography is relatively flat, so such corals are likely more resistant to the quake vibration. In the period 2007 to 2010 in this area was not found the meaningfull magnitude of quakes (Figure 4 , left) therefore, it showed valuable progression of the live corals coverage (Figure 4 , right). As well as monitoring data in 2015, the percentage of live coral coverage at station 1 to 6 increase range from $1.1 \%$ to $7.5 \%$ (Figure 4, right).

GCRMN (2005) and Hagan et al. (2007) stated that the coral reefs in the Indian Ocean after earthquake will recover from the damages within the next 5-10 years.

\section{Mangrove}

Blasco et al. (1996) from his studies reported degraded mangrove'plant due to land lifting after earthquake in Guyana, Gambia, Côte d'Ivoire, Kenya, India and Bangladesh, shows Rhizophora, Bruguiera, Sonneratia, Heritiera ecologically this plant has limitations of salinity tolerance and the duration of inundation process of ebb nd tide. However, according to Ray \& Acharyya (2011) mangroves can still survive in a land that still holds and retains moisture, salinity and nutrients are important. Mahendra et al. (2006) suggested old trees of existing mangroves still produce seeds, will always growing and developing (spreading progression) in the direction of the sea The process of spreading progressions of the mangrove after earthquake and land uplifted has also been occured in the Andaman Islands.

In the village of Lahewa, after quake and followed by $2.5 \mathrm{~m}$ land uplifted, caused most of the mangrove community is experiencing drought. Based on the analysis of coastal profile (Figure 5) also shows that the tidal were no reach out to the mangroves. However, based on the analysis of the landsat image aquired in 2015 showed in the rear zone of the mangroves (southern part, farthest from the shorelines) degraded with a width varying between $40 \mathrm{~m}$ upto $480 \mathrm{~m}$. UNEP (2007) reported Rhizophora trees had become desiccated and died slowly but several trees of Cheriops appear stayed on the dry land condition and seemed to be growing normally. WIIP (2006) also reported that although there were no tidal inundate, several species 
of Aegiceras corniculatum, Dolichandrone spathacea, Xylocarpus rumphii, Ceriops decandra able to survive in the new environment which is relatively dry.

\section{CONCLUSION}

Nias earthquake in 2005 in shallow waters has caused most of the coral was broken, partially lifted into the mainland and most die of drought while in deeper waters, coral damage was caused by the vibration of earthquake. In the period of 2007 to 2010 has shown the coral recovery, but in the earthquake that occurred in 2012 is thought to play an important role to destroy the coral and it is seen in the result of reef health monitoring in 2014. Coral, especially branching corals grows in the slope environment are easily collapsed by quake vibrations.

Similarly, mangrove that has been lifted, moved away from the shoreline and tides no longer reached the mangroves. Mangroves in the farthest part of the shore has been destroyed particularly Rhizophora is very vulnerable to drought so it will die slowly. But other species such as Cheriops, Aegiceras, Xylocarpus and Dolychandrone to be growing normally.

The series of events occurring in Nias are lessons learnt: close relationship between coastal ecosystem development and earthquake activities to consider the selection of a marine conservation areas in the tectonically active such as west of Sumatera.

\section{ACKOWLEDGEMENTS}

We thank to Sabar Jaya Telaumbanua, M.Si of Marine Agency of North Nias Regency facilitated the research, thank is also to Rikoh M Siringoringo M.Si, as a research coordinator of the Research Center for Oceanography LIPI for the help of field facilities, information and ease of access to data. Without them this work would not have been possible.

\section{REFFERENCE}

Armstrong, R.A. (1993). Remote sensing of submerged vegetation canopies for biomass estimation. Int. J. Remote Sens., 14, 621-627.

Aronson, R.B., Precht, W.F., Macintyre, I.G. \& Toth, L.T. (2012). Catastrophe and the life span of coral reefs. Ecology 93(2), 2012, pp. 303-313.

BBC New 11 April 2012. Tsunami warning cancelled after 8.6 Indonesia earthquake. Available from: http://www.bbc.com/news/world-17683333. [Accessed 14 August 2015].

Blasco, F., Saenger, P. \& Janodet, E. (1996). Mangroves as indicators of coastal change. Catena 27 (3-4), 167-178.

Chasanah, U., Madlazim. \& Prastowo, T. (2013). Analysis of seismicity level and earthquake return period in West Sumatra Region in the Period 1961-2010. Inovasi Fisika Indonesia 2(2),1-6. in bahasa Indonesia.

Dahdouh-Guebas, F. (2002). The use of remote sensing and GIS in the sustainable management of tropical coastal ecosystems. Environment, Development and Sustainability 4, 93-112.

Devi, E.U. \& Shenoi, S.S.C. (2012). Tsunami and the Effects on Coastal Morphology and Ecosystems: A Report. Proc Indian Nat. Sci. Acad. 78 (3), 513521.

Duputel, Z., Kanamori, H., Tsai, V.C., Rivera, L., Meng, L., Ampuero, J.P. \& Stock, J.M. (2012). The 2012 Sumatra great earthquake sequence. Earth and Planetary Science Letter 351-352: 247-257.

GCRMN (Global Coral Reef Monitoring Network). (2005). Status of coral reefs in tsunami affected countries:2005. (Wilkinson, Souter and Goldberg eds.): $154 \mathrm{p.}$

Hagan, A.B., Foster, R., Perera, N., Gunawan, C.A., Silaban, I., Yaha, Y., Manuputty, Y., Hazam, I. \& Hodgson, G. (2007). Tsunami and coral reef. Atoll Research Bulletin 544, 37-54.

Handayani, L., Permana, H. \& Gaffar, E.Z. (2012). Segmentation of active micro plate tectonics in Northern Sumatra (Aceh) reviewed from earthquake epicenter distribution. Jurnal Lingkungan dan Bencana Geologi 3(2), 71-77. in bahasa Indonesia.

Lillesand, T.M. \& Kiefer, R.W. (1994). Remote sensing and image interpretation. John Wiley and Sons, Inc. New York, 750 p.

Lyzenga, D.R. (1978). Passive remote sensing techniques for mapping water depth and bottom features. Appl. Opt. 17, 379-383.

Mahendra, R.S., Mohanty, P.C., Bisoyi, H. \& Srinivasa, K.T. (2014). Geospatial assessment of coral and mangrove environs of the Andaman Islands. International Journal of Earth Sciences and Engineering 7(1), $275-279$.

Maritorena, S. (1996). Remote sensing of the water attenuation in coral reefs: a case study in French Polynesia. Int. J. Remote Sens., 17, 155-166. 
Mc Adoo, B.G., Fritz, H.M., Jackson, K.L., Kalligeris, N., Kruger, J., Bonte-Grapentin, M., Moore, A.L., Rafiau, W.B,, Billy, D. \& Tiano, B. (2008). Solomon Islands Tsunami, One Year Later. EOS, Transaction, American Geophysical Union 89(18), 169-176.

Mishra, D., Narumalani, S., Rundquist, D. \& Lawson, M. (2006). Benthic habitat mapping in tropical marine environments using QuickBird multispectral data. Photogrammetric Engineering \& Remote Sensing 72 (9), 1037-1048.

Ray, S.K. \& Acharyya, A. (2011). Coseismic uplift, slow plant mortality and ecological impact in North Andaman following the December 2004 (Mw > 9.2) earthquake. Current Science 101 (2), 218 222.

Saraswati, A.A. (2004). Management concept on coastal ecosystem (case study in Ulujami District, Pemalang Regency, Central Java. Jurnal Teknologi Lingkungan 5(3),205-211. in bahasa Indonesia.

Suyarso. (2008). Topographic changes after 2004 and 2005 earthquakes at Simeulue and Nias islands identified using uplifted reefs. Jour. Coast. Dev. 12 (1), 20-29.

Theguardian 11 April 2012 . Indonesia lifts tsunami alert after 8.6-magnitude earthquake: Panic and traffic jams triggered in Aceh after post-earthquake tremors also felt in Singapore, Thailand, Malaysia and India. Available from:https://www. theguardian.com/world/2012/apr/11/indonesiatsunami-warning-earthquake - aceh. [Accessed 14 August 2015].

Tugiyono. (2010). Evaluate the fertility of coastal waters ecosystems in Sriminosari village, Labuhan Maringai district, Lampung Timur Regency, Lampung. Proceedings of the National Seminar on Limnology V 2010, 61-75.

UNEP (United Nations Environment Programme). (2007). After the Tsunami: Coastal Ecosystem Restoration, Lessons Learnt in Aceh since the Tsunami $55 \mathrm{p}$.

USGS. (2008). Map of Seismic Hazard of Western Indonesia. Map prepared by U.S. Geological Survey, National Earthquake Information Center, April 2008.

USGS. (2016). Earthquake Notification Service. Available from: http://sslearthquake.usgs.gov/ ens/. [Accessed 17 August 2015].

Vargas, G., Farías, M., Carretier, S., Tassara, A., Baize, S. \& Melnick, D. (2011). Coastal uplift and tsunami effects associated to the 2010 Mw8.8 Maule earthquake in Central Chile. Andean Geology 38 (1), 219-238.

Vatria, B. (2010). Various human activities that can lead to degradation of coastal ecosystems and their impacts. Jurnal Belian 9 (1), 47- 54. In bahasa Indonesia

Villalobos, F. (2012). Crustal deformation associated with the 1960 earthquake events in the South of Chile. 5th International Conference on earthquake geotechnical engineering. Santiago, Chile, Paper No. CDDFV.

WIIP (Wetlands International Indonesia Programme) (2006). Study of Lessons Learned from Mangrove/Coastal Ecosystem Restoration Efforts in Aceh since the Tsunami (Wibisono ITW and Suryadiputra IN eds.). Bogor, $89 \mathrm{p}$. 
Progress on Coastal Ecosystems: .... in North Nias, North Sumatera (Suyarso., et al.) 